\title{
Peach phenological characters: heritability, maternal effect and correlation with brown rot
}

\author{
M. Dini ${ }^{1}$, M.C.B. Raseira ${ }^{2}$, S. Scariotto ${ }^{3}$, P.M. Marchi ${ }^{4}$ and \\ P. Mello-Farias ${ }^{4}$ \\ ${ }^{1}$ Universidade Federal de Pelotas, Capão do Leão/RS, Brasil \\ Researcher. Instituto Nacional de Investigación Agropecuaria (INIA). \\ Programa Nacional de Investigación en Producción Frutícola. Estación \\ Experimental INIA Las Brujas, Canelones, Uruguay \\ ${ }^{2}$ Embrapa Clima Temperado, Pelotas, Rio Grande do Sul, Brasil \\ ${ }^{3}$ Universidade Tecnológica Federal do Paraná, Pato Branco, Paraná, Brasil \\ ${ }^{4}$ Universidade Federal de Pelotas, Capão do Leão, Rio Grande do Sul, Brasil \\ Corresponding author: M. Dini \\ E-mail: mdini@inia.org.uy
}

Genet. Mol. Res. 20 (1): gmr18684

Received November 19, 2020

Accepted December 15, 2020

Published January 31, 2021

DOI http://dx.doi.org/10.4238/gmr18684

\begin{abstract}
Peach is a temperate fruit species that is cultivated under various edaphoclimatic conditions all over the world. In Brazil, in the early 1950s, peaches were planted only in São Paulo state and in the Southern states, and the harvest period was restricted to 15 days. Currently, mainly due to peach breeding programs, it is cultivated in subtropical areas and even in high altitude tropical areas, with a harvest period of over 100 days. Knowledge of genetic, phenotypic and environmental parameters that influence characters of economic importance is crucial for guiding breeding programs. The objectives of this study were to estimate the heritability of phenological characters, to evaluate their distribution within populations, to test the possible existence of maternal effect and to evaluate the relationship of these traits with brown rot incidence (Monilinia fructicola). The study was performed in Pelotas, RS, Brazil during 2015-2016 to 2017-2018 seasons. Sixteen first generation $\left(F_{1}\right)$ progenies were evaluated, 10 of them being reciprocal
\end{abstract}


crosses. All genotypes were cultivated in the same area, under the same cultural practices (without fungicide application). Full bloom was considered when more than $50 \%$ of flowers were open, and the harvest, when more than 10 fruits reached commercial maturity, the fruit development period being calculated by the difference between full bloom and harvest dates. Brown rot incidence was estimated by the percentage of fruits with symptoms. Broad-sense heritability estimates for full bloom date, harvest date, and fruit development period were high (95 to $98 \%$ ), and narrow-sense heritabilities were medium to high (65 to $72 \%$ ). A segregation study of these traits suggests a maternal effect on their heritability, mainly for full bloom and harvest date. The three phenological characters were significantly correlated, and only harvest date had a negative and significant correlation (-0.12) with brown rot incidence.

Key words: Prunus persica; Monilinia fructicola; Progeny segregation

\section{INTRODUCTION}

Peach (Prunus persica) is a temperate fruit that has been adapted to many different growing conditions. Successful exploitation of this crop depends mostly on its location and choice of the appropriate cultivar (Raseira et al., 2014). In Brazil, until the 1950s, the species was only cultivated in the Southern region of the country and in São Paulo state. In the South, the harvest period was restricted to 15 days, with two commercial cultivars (Raseira et al., 2014). Nowadays, the planting has expanded to other subtropical areas and even to high altitude tropical areas (Citadin et al., 2014). The harvest period has been extended to more than 100 days, and there are, approximately, 100 peach cultivars destinated for fresh fruit consumption, industry or dual purpose, besides nectarine cultivars. This is, in great part, due to national peach breeding programs (Pommer and Barbosa, 2009; Raseira et al., 2014).

Flowering and harvest date and fruit development are important phenological traits for peach production, especially to determine the adequate cultivar for growers, and for cultural practice decision-making. The flowering date, mainly the date of full bloom, is very important, especially in regions where frost occurrs, because flowers and young fruits are very sensitive to frost damage, and later bloom can be an alternative to avoid such damage (Dirlewanger et al., 2012; Citadin et al., 2014; Raseira et al., 2014). Flowering date is a complex character, and the genetic components have not yet been clearly identified. Besides the influence of chilling accumulation to complete dormancy, heat requirements (number of days of warm temperatures needed after dormancy suppression) has to be achieved for normal and uniform flowering (Razavi et al., 2011; Carpenedo et al., 2017; 2020; Fadón et al., 2020). At the same location, flowering dates may differ along the years, but flowering sequence remains relatively constant among cultivars year after year (Byrne et al., 2012; Raseira et al., 2014).

Harvest date is another goal of most breeding programs due to its importance for the productive system, either due to the demand to substitute some commercial cultivars for new ones with higher production and quality, or for the necessity to extend the harvest 
period. Ripening date is considered a polygenic inheritance character, involving major and minor genes (Byrne et al., 2012; Raseira et al., 2014).

The importance of the fruit development period is, in part, due to the possibility of having early ripening cultivars, with late bloom, which may escape from frost occurrence. Short fruit development period brings benefits to growers, since the commercial value is improved, and the production costs and risks are reduced due to the shorter period that fruits remain on the tree. The risks to which the fruit is subjected (wind, hail, pests, diseases, among others) are higher in long-cycle cultivars. Besides reducing risks and costs, when peach trees are cultivated in humid and rainy regions, brown rot (Monilinia spp.) incidence is higher (May-de Mio et al., 2008; Mondino et al., 2010; Raseira et al., 2014), requiring frequent fungicide pulverizations, almost every week. This, increases grower's and consumer's concern about health and environmental contamination risks (Elshafie et al., 2015; Baró-Montel et al., 2019), as well as the generation of fungus strains resistant to fungicides (Luo et al., 2010; Hily et al., 2011; Zhu et al., 2012; Chen et al., 2017; Fu et al., 2017).

The knowledge of genetic, phenotypic, and environmental parameters, which directly or indirectly, influences economically important crop traits is fundamental for breeding program design (Ramalho et al., 2012). Taking these concerns into consideration, the aim of this research was to estimate full bloom, harvest date and fruit development period heritability, as well as to evaluate their distribution in the first generation $\left(\mathrm{F}_{1}\right)$ of peach progenies, testing for maternal effects and the relationship of these characters with brown rot incidence.

\section{MATERIAL AND METHODS}

The experiment was performed at Embrapa Clima Temperado, Pelotas, Rio Grande do Sul, Brazil (31 ${ }^{\circ} 40^{\prime} \mathrm{S}, 52^{\circ} 26^{\prime} \mathrm{W}$, alt. $57 \mathrm{~m}$ ) during the 2015-2016, 2016-2017 and 20172018 growing seasons. All genotypes were cultivated in the same area (Embrapa work collection), under the same cultural and chemical management. The fungicides application was minimal, being restricted to winter and spring applications.

Sixteen first generation $\left(F_{1}\right)$ progenies originated from controlled crosses were evaluated, 10 of them being reciprocal crosses. The peach parents, corresponding to different cultivars and advanced selections, were also evaluated (Table 1).

$\mathrm{F}_{1}$ progenies were planted in an experimental orchard with trees spaced at $0.5 \mathrm{~m}$ within rows and $5 \mathrm{~m}$ between rows, where each tree corresponded to a different individual (seedling). The 2008.159 and 2009.38 progenies were between six and 10-years-old, and all other progenies began the study as three and ended as six-years-old. Parents had been planted before the trial at working collections orchards in the surrounding area, and trees were spaced at $2 \mathrm{~m}$ within rows and $5 \mathrm{~m}$ between rows. Each parent consisted of three trees (between 10 and 14-years-old), propagated by budding (clones).

Observations were made for each tree in order to obtain the phenological dates of beginning and full bloom ( $10 \%$ and $>50 \%$ of opened flowers, respectively); and beginning of harvest time. Dates were transformed into number of days, starting on June 1. Beginning of harvest was considered when at least 10 fruits reached commercial maturity, and fruit development period was calculated by the interval (in days) between the date of full bloom and the harvest date. 
Table 1. Parents of $F_{1}$ progenies and number of seedlings of each progeny, in the Peach Breeding Program at Embrapa Clima Temperado, Pelotas, Rio Grande do Sul, Brazil.

\begin{tabular}{|c|c|c|c|c|}
\hline \multirow{2}{*}{\multicolumn{2}{|c|}{$F_{1}$ progeny identification }} & \multicolumn{2}{|c|}{ Parents } & \multirow{2}{*}{$\begin{array}{l}\text { No. of } \\
\text { seedlings }\end{array}$} \\
\hline & & q & $\hat{\sigma}$ & \\
\hline \multirow{16}{*}{ 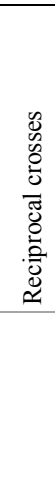 } & 2008.159 & Conserva 1526 & 'Cerrito' & 7 \\
\hline & 2009.38 & 'Cerrito' & Conserva 1526 & 23 \\
\hline & 2012.26 & Cascata 1055 & 'Chimarrita' & 18 \\
\hline & 2012.43 & 'Chimarrita' & Cascata 1055 & 25 \\
\hline & 2012.49 & Conserva 672 & Conserva 1526 & 18 \\
\hline & 2012.61 & Conserva 1526 & Conserva 672 & 7 \\
\hline & 2012.52 & Conserva 947 & Conserva 1600 & 17 \\
\hline & 2012.66 & Conserva 1600 & Conserva 947 & 12 \\
\hline & 2012.68 & Conserva 1662 & 'Maciel' & 24 \\
\hline & 2012.88 & 'Maciel' & Conserva 1662 & 17 \\
\hline & 2012.31 & Cascata 1359 & Cascata 1577 & 31 \\
\hline & 2012.46 & Chorão & 'Maciel' & 25 \\
\hline & 2012.99 & Necta 506 & 'Sunmist' & 20 \\
\hline & 2012.107 & Necta 532 & Necta 480 & 25 \\
\hline & 2012.111 & Necta 540 & 'Morena' & 25 \\
\hline & 2012.114 & 'BRS Rubimel' & TX2D163 & 21 \\
\hline
\end{tabular}

The variance observed between the three clones of each parent gave the environmental effect estimation, and the parents' variances average was used as the average environmental variance $\left(\sigma_{\mathrm{e}}{ }^{2}\right)$. The observed variance among plants of the same progeny was used as the total phenotypic variance $\left(\sigma_{\mathrm{p}}{ }^{2}\right.$ - genetic plus environmental effects). The genetic variance $\left(\sigma_{\mathrm{g}}{ }^{2}\right)$ was calculated by subtracting the environmental variance from the total variance of each progeny (Centellas-Quezada, 2000; Côrrea, 2007; Wagner Júnior et al., 2008). Broad-sense heritability $\left(H^{2}\right)$ was estimated dividing the genetic variance of each population by the total variance, as shown in the following calculation formula (Allard, 1960; Dirlewanger et al., 2012; Griffiths et al., 2015):

$$
H^{2}=\frac{\hat{\sigma}_{\mathrm{g}}^{2}}{\hat{\sigma}_{\mathrm{g}}^{2}+\frac{\hat{\sigma}_{e}^{2}}{e}}
$$

Where: $\hat{\sigma}_{\mathrm{g}}^{2}=$ estimated genetic variance; $\hat{\sigma}_{\mathrm{e}}^{2}=$ estimated environmental variance; $e=$ number of environments (seasons of experiment).

Narrow-sense heritability $\left(h^{2}\right)$ estimates were obtained by linear regression between the average parent and progenies values. The estimated value of $h^{2}$ corresponds to the slope of the regression line, which means, the regression coefficient " $b$ " of the linear equation $Y=$ $a+b x$ (Griffiths et al., 2015).

Frequency distribution and their histograms were built with fruit development period data, measured in days; and full bloom and harvest date, expressed in days from June 1 .

The maternal effect was evaluated by comparing the population of each cross with its reciprocal, testing the three phenological characters studied (full bloom, harvest date and fruit development period) by the Mann-Whitney test at 5\% of probability. This nonparametric test was used due to the nature of the variables (days), being discrete quantitative variables; with two independent samples; without a normal distribution; and presenting 
populations with different number of individuals. Using the median, as the central distribution parameter, the following contrasts were tested: $F_{1}$ versus (vs.) $F_{1}$ reciprocal, $P_{f} v s . P_{m}, P_{f}+P_{m}$ vs. $\mathrm{F}_{1}, \mathrm{P}_{\mathrm{f}}$ vs. $\mathrm{F}_{1}, \mathrm{P}_{\mathrm{m}}$ vs. $\mathrm{F}_{1}, \mathrm{P}_{\mathrm{f}}+\mathrm{P}_{\mathrm{m}}$ vs. $\mathrm{F}_{1}$ reciprocal, $\mathrm{P}_{\mathrm{f}}$ vs. $\mathrm{F}_{1}$ reciprocal, $\mathrm{P}_{\mathrm{m}}$ vs. $\mathrm{F}_{1}$ reciprocal. Where $\mathrm{P}_{\mathrm{f}}$ is the female parent, $\mathrm{P}_{\mathrm{m}}$ the male parent and $\mathrm{F}_{1}$ the progeny of hybrid individuals (Londero et al., 2009; Wu et al., 2012).

Brown rot incidence (BRI) was estimated by the percentage of fruits with symptoms in relation to the total number of fruits in the orchard, without inoculation. BRI and the phenological characters (full bloom, harvest date and fruit development period) were analyzed with Spearman's correlation using R software (R Core Team, 2020).

\section{RESULTS AND DISCUSSION}

High variability associated with full bloom and harvest date characters was observed in the populations, evidenced by full bloom and harvest date intervals, 36 to 87 days and 138 to 230 days, respectively, both from June 1 . These intervals were closely aligned to the average values of the parents, 42 to 80 and 141 to 215 , for full bloom and harvest date, respectively (Figures 1 and 2). The variability observed in these characters has already been mentioned and studied in several other studies, including Hartmann (2013) and Frett (2016).

High variability was also observed for the fruit development period character, indicated by the interval of 72 to 178 days among the individuals of the progenies (Figure 3 ). This result was expected, since the same character among the parents ranged from 81 to 157 days, and due to the fact that additive genes determine this character (Vileila-Morales et al., 1981; Souza et al., 1998). Our study values are similar to those found by Hartmann (2013), who evaluated nine progenies and eight parents for fruit development period, and observed high variability for this character, with intervals of 50 to 159 days and 66 to 133 days, for the progenies and the parents, respectively.
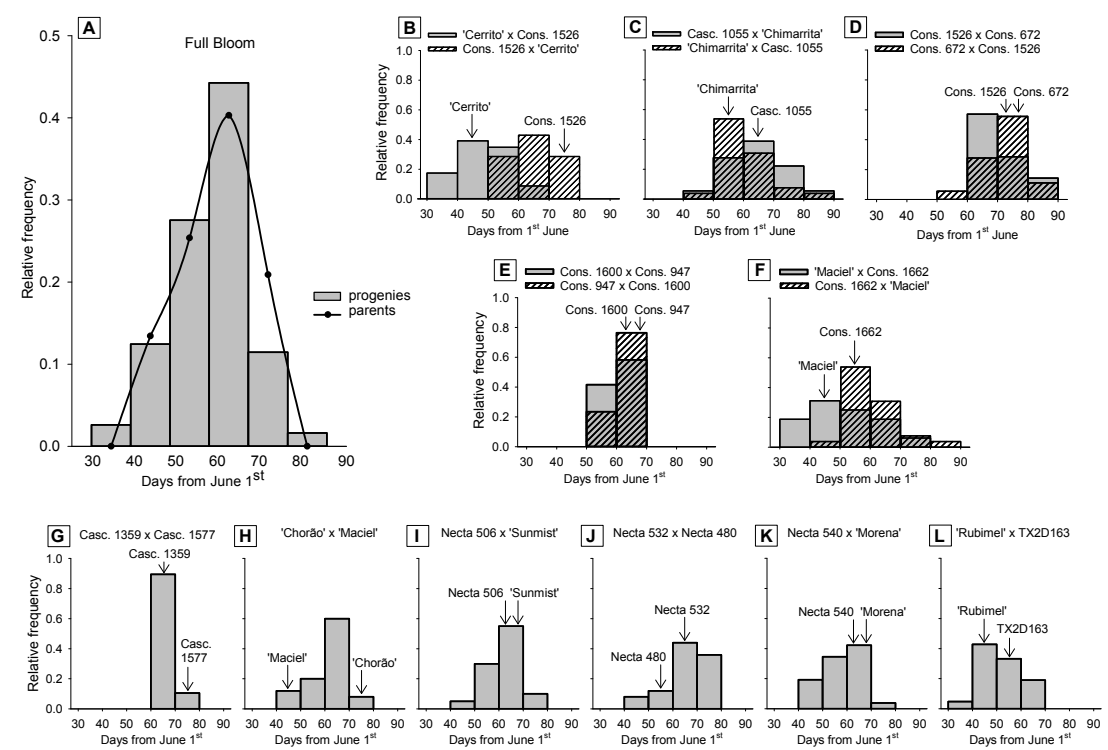

Figure 1. Full bloom histograms for peaches (expressed in days from June 1). Frequency of seedlings for all progenies and all parents used on the study $(A)$, individual $F_{1}$ progenies (B to $L$ ), $B$ to $F$ being reciprocal crosses. Arrows represent parents. Peach Breeding Program at Embrapa Clima Temperado, 2015-2016, 2016-2017 and 2017-2018 growing seasons, Pelotas, Rio Grande do Sul, Brazil. 

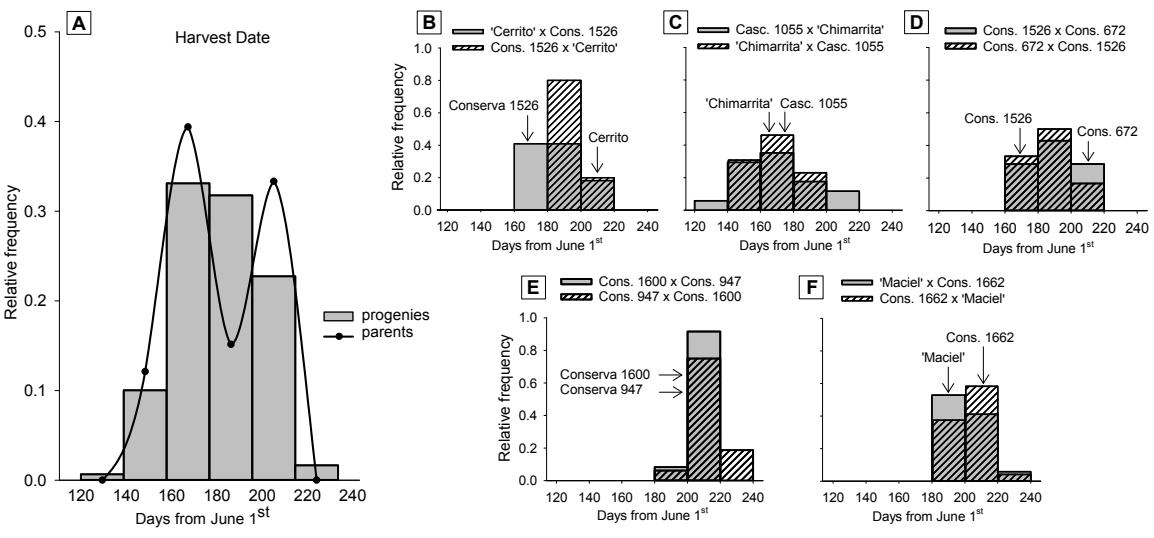

F $\rightleftharpoons$ 'Maciel' $x$ Cons. 1662

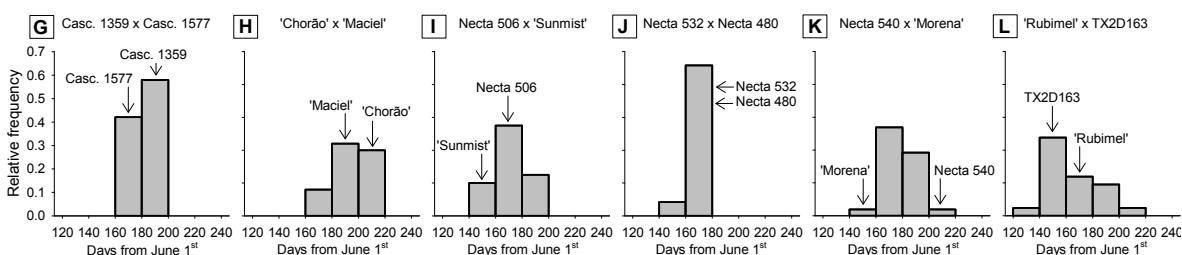

Figure 2. Peach harvest date histograms (expressed in days from June $1^{\text {st }}$ ). Frequency of seedlings for all progenies and all parents used on the study (A), individual $\mathrm{F}_{1}$ progenies (B to $\mathrm{L}$ ), $\mathrm{B}$ to $\mathrm{F}$ being reciprocal crosses. Arrows represent parents. Peach Breeding Program at Embrapa Clima Temperado, 2015-2016, 2016-2017 and 2017-2018 growing seasons, Pelotas, Rio Grande do Sul, Brazil.
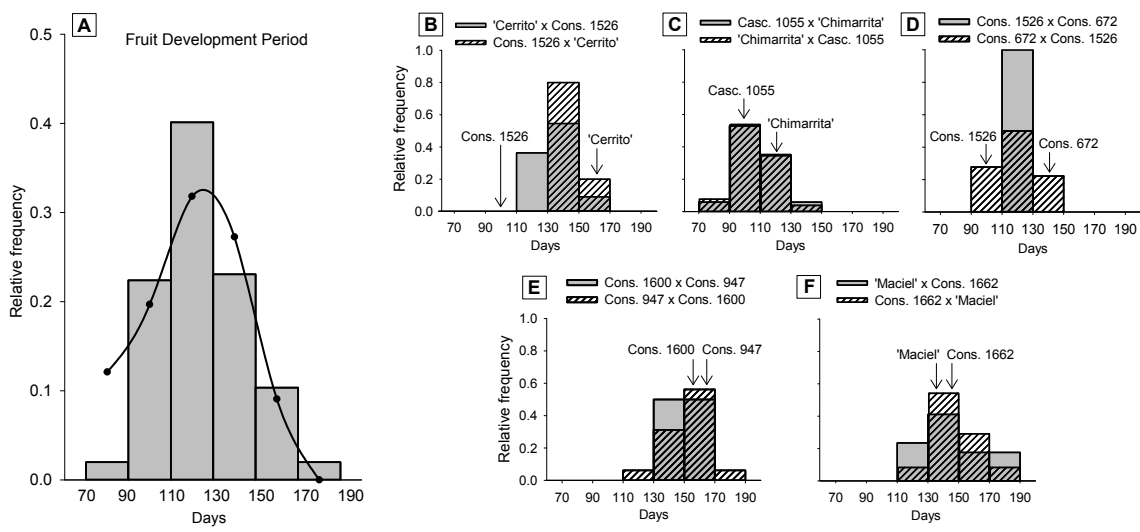

F 2 'Maciel' $x$ Cons. 1662
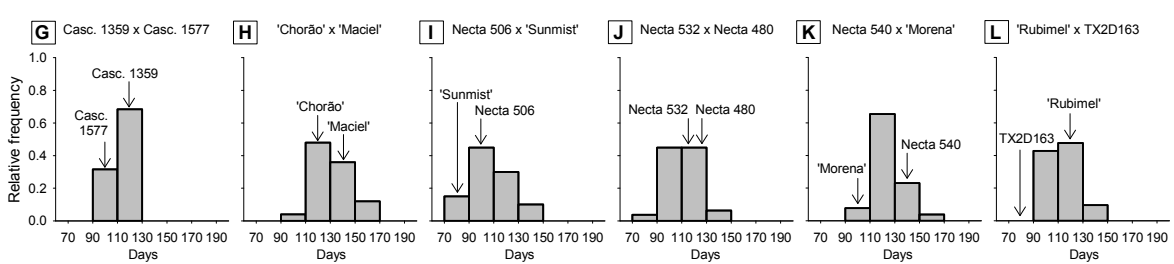

Figure 3. Peach fruit development period histograms (expressed in days). Frequency of seedlings for all progenies and all parents used on the study (A), individual $F_{1}$ progenies (B to $L$ ), being $B$ to $F$ reciprocal crosses. Arrows represent parents. Peach Breeding Program at Embrapa Clima Temperado, 2015-2016, 2016-2017 and 2017-2018 growing seasons, Pelotas, Rio Grande do Sul, Brazil. 
For full bloom, harvest date and fruit development period characters, the $H^{2}$ estimated values were very high (Table 2). These results are similar to those found in other publications, where the authors agree that broad-sense heritability for these characters is high to very high. Values such as 98\% (Centellas-Quezada, 2000), 67 to 89\% (Dirlewanger et al., 2012), and 82\% (Hartmann, 2013) are mentioned for full bloom. Furthermore, for harvest date, $H^{2}$ was estimated, ranging from 76 to $99 \%$ (Dirlewanger et al., 2012), 92\% (Hartmann, 2013), and 58-80\% (Frett, 2016). For fruit development period, Hartmann (2013) estimated $H^{2}=91 \%$, and Corrêa (2007) from 90 to $92 \%$.

Table 2. Broad-sense $\left(H^{2}\right)$ and narrow-sense $\left(h^{2}\right)$ estimated heritability for full bloom (FB), harvest date (HD) and fruit development period (FDP) in peach progenies of the Peach Breeding Program at Embrapa Clima Temperado, 2015-2016, 2016-2017 and 2017-2018 growing seasons, Pelotas, Rio Grande do Sul, Brazil.

\begin{tabular}{llllll}
\hline & \multirow{2}{*}{$\boldsymbol{H}^{\mathbf{2}}$} & \multicolumn{3}{c}{$\boldsymbol{h}^{\mathbf{2}}$} \\
\cline { 3 - 6 } & & $\mathbf{2 0 1 5} / \mathbf{1 6}$ & $\mathbf{2 0 1 6 / 1 7}$ & $\mathbf{2 0 1 7 / 1 8}$ & Mean \\
\hline FB & $96.21^{(1)}$ & 59.29 & 85.04 & 62.42 & 68.92 \\
HD & 98.43 & 66.51 & 81.55 & 68.64 & 72.23 \\
FDP & 95.29 & 71.27 & 72.75 & 52.78 & 65.60 \\
\hline (1)
\end{tabular}

${ }^{(1)}$ All estimated heritability values were expressed as a percentage (\%).

The estimation of $H^{2}$ is not the most useful for plant breeders, $h^{2}$ being more important, and it is calculated by dividing the additive genetic variance by the total phenotypic variance. The selection effect does not depend on the total genetic variance, but on the magnitude of the additive genetic variance. Consequently, $h^{2}$ is more relevant to predict the selection response (Griffiths et al., 2015).

The $h^{2}$ estimates for full bloom were from 59.29 to $85.04 \%$, according to the evaluated growing season, with an average of $68.92 \%$ (Table 2). The $h^{2}$ mean value for full bloom is similar and intermediate in comparison to those estimated by Hansche (1990) who found 60\%, by Hartmann (2013) with $62 \%$, and by Souza et al. (1998) with $78 \%$; and it is almost twice the estimated value found in Hansche et al. (1972), which was 39\%.

Narrow-sense heritability for harvest date was estimated to range from 66.51 to $81.55 \%$, with an average of $72.23 \%$ (Table 2). This value is similar to other estimates for this character, 72\% (Frett, 2016), 79\% (Hansche et al., 1972), and lower than the estimates observed by Hansche (1986) and Souza et al. (1998), which were $84 \%$ and $94 \%$, respectively. Another estimate found by Hartmann (2013) was 7\%, different from the previous values. The same author mentioned that such a low estimate for this character was not expected and justified it by stating that the additive genetic variance only explained $4 \%$ of the phenotypic variance, while the non-additive genetic component was responsible for $51 \%$ of the total phenotypic variance, indicating the presence of major genes associated with this characteristic. In our study, on average, there was a slight tendency towards the early parents (Figure 1).

In addition, $h^{2}$ for fruit development period was estimated to be between 52.78 and $71.27 \%$, with an average of $65.60 \%$ (Table 2). This value was lower than that estimated by Souza et al. (1998), who obtained 91\%, but was similar to the one found by Corrêa (2007), with $65 \%$, for the same character. These authors concluded that $h^{2}$ for fruit development period in peach trees was very high and high, respectively, in contrast with the estimated values $(6 \%)$ by Hartmann (2013). According to Hartmann (2013), this low value was due to the estimated additive genetic component, which explained only $3 \%$ of the total phenotypic variation, while the non-additive genetic component was responsible for $44 \%$ of the total phenotypic variation, 
indicating the association of major genes with this characteristic. It is interesting to point out that the populations studied by Hartmann (2013) were different than the ones available in Brazil.

In most cases, studies that approach phenological characters such as the ones tested in this study indicated that they are considered highly transmissible characters. In other words, they are easily inherited, since narrow-sense heritability is high to very high, and, therefore, selection based on phenotype is effective (Allard, 1960; Falconer and Mackay, 2001).

The evaluated characters were strongly affected by environmental effects, mainly FB. The 2015-2016 and 2017-2018 growing seasons showed insufficient accumulation of chilling hours below $7.2^{\circ} \mathrm{C}$ ( 74 and 77 hours, respectively) and higher temperatures than the historical averages in the winter and spring. This leads to an earlier and irregular flowering, influencing the other two characters (harvest date and fruit development period). In the 2016-2017 growing season, the three phenological characters had the highest $h^{2}$ estimates, due to the lower environmental influence (smaller $\hat{\sigma}_{\mathrm{e}}^{2}$ ). During the winter of 2016, according to the data obtained from the weather station of Embrapa Temperate Agriculture, the accumulation of chilling hours was 172, from May to September, positively affecting all genotypes that presented later and more concentrated flowering (Agromet-Embrapa, 2020).

The relative frequency distribution showed that, in general, the progenies average were similar to the average of their parents (Figures 1,2 and 3). The existence of transgressive segregation (individuals in the progenies with values below or above their parents') was generally verified for each one of the three characters and for most progenies, as also observed in previous studies (Hansche et al., 1972; Hansche, 1986; Souza et al., 1998; Corrêa, 2000; Hartmann, 2013; Frett, 2016).

According to the histograms, it was observed differences when using a female or male parent, since the progenies distribution is not the same when compared to their respective reciprocal progenies (Figures $1 \mathrm{~B}$ to $1 \mathrm{~F}, 2 \mathrm{~B}$ to $2 \mathrm{~F}$ and $3 \mathrm{~B}$ to $3 \mathrm{~F}$ ). Furthermore, it was noted a tendency to group a larger number of individuals within or near the female parent class; although, this has not happened in all the progenies. This trend, observed in the histograms for the three phenological characters evaluated could suggest some kind of maternal effect. When this occurs, heritability estimates that not considering this maternal effect could lead to a bias in the heritability coefficients estimates (Eler, 2014). Reciprocal crosses are the simplest evidence of maternal effect, since they produce individuals genetically similar but phenotypically different (Eler, 2014; Ramalho et al., 2012), if there is indeed a significant maternal effect. This tendency of individuals' concentration (seedlings) in the class corresponding to the female parent was previously mentioned by Corrêa (2007), for the fruit development period character, and by Frett (2016) in a harvest date study.

This possible effect was tested comparing contrasts for the three phenological characters studied by the Mann-Whitney test, and Figure 4 synthesizes the results. This scheme contains the five $F_{1}$ progenies with their reciprocal progenies, indicating the parents and progenies median values, and whether the contrast was significant or not.

Firstly, when parents were compared (female vs. male parent), in all cases and for the three characters, the difference between them was significant. On the other hand, for the contrasts between the reciprocal progenies $\left(F_{1}\right.$ vs. reciprocal $\left.F_{1}\right)$, only one of the reciprocal crosses was significant for the full bloom character (2008.159 vs. 2009.38). This indicates differences when using Conserva 1526 and 'Cerrito', as female or male parents, since the progenies generated by them were statistically different. In the other reciprocal crosses and in all the harvest date and fruit development period characters contrasts, there were no significant differences between the reciprocal progenies, indicating that there is no difference for this character when using one of the parents as female or male. 
When the two parents were confronted with their progenies, $P_{f}+P_{m}$ vs. $F_{1}$ e $P_{f}+P_{m}$ vs. $F_{1}$ reciprocal contrast, only three out of 30 tested contrasts showed significant differences. One cross for each character was used; for full bloom, it was 'Chimarrita' + Cascata 1055 vs. 2012.43, and for harvest date and fruit development period, it was Conserva $1662+$ 'Maciel' vs. 2012.68. For the first crossing, the progenies were closer to the female parent ('Chimarrita'), which had earlier flowering. In the other two significant crosses, the progeny was also closer to the female parent (Conserva 1662), with later harvest date and longer fruit development period. In the remaining contrasts, there was no significant difference, indicating that the median of full bloom, harvest date and fruit development period of the parent is equal to their progenies' median.

For full bloom character (Figure $4 \mathrm{~A}$ ), when $\mathrm{P}_{\mathrm{f}} \mathrm{vs} . \mathrm{F}_{1}, \mathrm{P}_{\mathrm{m}}$ vs. $\mathrm{F}_{1}, \mathrm{P}_{\mathrm{f}}$ vs. $\mathrm{F}_{1}$ reciprocal e $\mathrm{P}_{\mathrm{m}}$ vs. $F_{1}$ reciprocal were confronted, i.e., the male and female parents were separately against their own progenies. It was observed only five crosses with significant differences out of the 20 tested contrasts, and four of these correspond to the male parent against their progeny. Thereby, there is a trend towards the female parent for the full bloom character, since nine out of ten contrasts among the female parents against their own progenies showed no significant differences. However, no major differences were observed between male parents against their own progenies, where four of them showed significant differences and six did not.

When studying the $P_{\mathrm{f}}$ vs. $\mathrm{F}_{1}, \mathrm{P}_{\mathrm{m}}$ vs. $\mathrm{F}_{1}, \mathrm{P}_{\mathrm{f}}$ vs. $\mathrm{F}_{1}$ reciprocal and $\mathrm{P}_{\mathrm{m}}$ vs. $\mathrm{F}_{1}$ reciprocal contrasts analysis in the harvest date character (Figure 4B), it was observed that five out of 20 tested contrasts were significant, and four of these correspond to the male parent against its progeny. In the same way as observed for full bloom, a trend towards the female parent was identified.

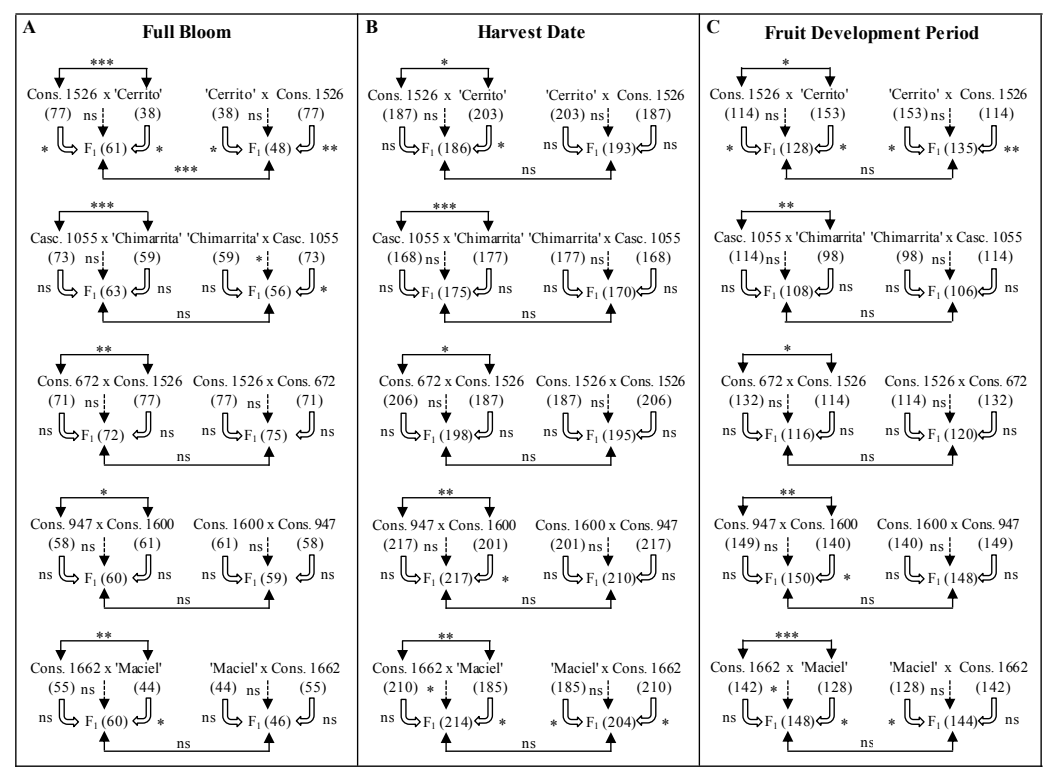

Figure 4. Parental and $F_{1}$ peach progenies and $F_{1}$ reciprocal, with their respective median values (parentheses) for the full bloom (A), harvest date (B) (expressed in days from June $1^{\text {st }}$ ) and fruit development period (C) (expressed in days). Significance was tested with the Mann-Whitney test in the contrasts between $F_{1}$ vs. $F_{1}$ reciprocal, female parental $\left(\mathrm{P}_{\mathrm{f}}\right)$ vs. male parental $\left(\mathrm{P}_{\mathrm{m}}\right), \mathrm{P}_{\mathrm{f}}+\mathrm{P}_{\mathrm{m}}$ vs. F1, $\mathrm{P}_{\mathrm{f}}$ vs. $\mathrm{F}_{1}, \mathrm{P}_{\mathrm{m}}$ vs. $\mathrm{F}_{1}, \mathrm{P}_{\mathrm{f}}+\mathrm{P}_{\mathrm{m}}$ vs. $\mathrm{F}_{1}$ reciprocal, $\mathrm{P}_{\mathrm{f}}$ vs. $\mathrm{F}_{1}$ reciprocal, and $\mathrm{P}_{\mathrm{m}}$ Vs. $\mathrm{F}_{1}$ reciprocal. ${ }^{\mathrm{ns}}, *, * *$ and $* * *$, nonsignificant and significant at $\mathrm{P} \leq 0.05, \leq 0.01$, and $\leq$ 0.001, respectively. Median values were calculated for three different growing seasons (2015-2016, 2016-2017 and 2017-2018). Embrapa Clima Temperado, Pelotas, Rio Grande do Sul, Brazil. 
For the fruit development period character (Figure 4C), in these same contrasts, it was observed that seven out of 20 tested contrasts were significant. Four of these correspond to the same cross and their reciprocal (Conserva $1526 \times$ 'Cerrito' and 'Cerrito' $\times$ Conserva 1526), and these parents were highly contrasting for fruit development period. In relation to the 16 remaining contrasts, only three were significant; two of the male parents against his own progeny and one of the female parents with his respective progeny. Thus, it can be highlighted again a slight tendency towards the female parent, although most of the contrasts were not significant, considering the parent medians to be equal to their $\mathrm{F}_{1}$ progenies medians.

In summary, after analyzing the individual progenies distribution for the three studied phenological characters and due to their high heritability estimates, it may be inferred that there is a predominantly genes additive action (Allard, 1960). Deviations could be attributed to genes of major effect or to a possible maternal effect (Roach and Wulff, 1987).

When the phenological characters were correlated with each other, all of them showed highly significant correlations (Table 3). A very high positive correlation was found between harvest date and fruit development period, indicating that the later the genotypes harvest, the larger is the fruit development period. Souza et al. (1998) and Hartmann (2013) also observed high correlations between these two characters. This could be expected since selection for low chill generally leads to early blooming, even in genotypes selected for harvest season.

Table 3. Spearman's correlation between phenological characters (full bloom, harvest date and fruit development period) and percentage of brown rot incidence in the peach progenies orchard of the Peach Breeding Program at Embrapa Clima Temperado, in 2015-2016, 2016-2017 and 2017-2018 growing seasons, Pelotas, Rio Grande do Sul, Brazil.

\begin{tabular}{|c|c|c|c|c|}
\hline & FB & HD & FDP & BRI \\
\hline $\mathrm{FB}^{(\mathrm{I})}$ & - & $* *$ & $* * *$ & ns \\
\hline $\mathrm{HD}^{(2)}$ & 0.144 & - & $* * *$ & $*$ \\
\hline $\operatorname{FDP}^{(3)}$ & -0.270 & 0.887 & - & $\mathrm{ns}$ \\
\hline $\mathrm{BRI}^{(4)}$ & -0.056 & -0.121 & -0.062 & - \\
\hline
\end{tabular}

Regarding BRI, the variability was very high and strongly affected by the rainfall occurrence during the harvest season. The percentage of BRI ranged from 0 to $100 \%$, with an average of $39.59 \%$ among all genotypes, on the three growing seasons evaluated (data not shown). The correlations between BRI and phenological characters only showed a low negative correlation with harvest date (Table 3), indicating that the later the harvest date, the lower is the BRI, and vice-versa. This last correlation can be explained because the late harvesting was originated by parents with certain degree of resistance to Monilinia fructicola infection; hypothesis that should be confirmed with controlled conditions trials.

\section{CONCLUSIONS}

The heritability of phenological characters (full bloom, harvest date, and fruit development period), in peaches, was found to be medium to high. The inheritance of the studied phenological characters is predominantly additive, and deviations can be attributed to maternal effects or major genes action. The phenological characters were correlated with each other and ibrown rot incidence was negatively correlated with the harvest date. 


\section{ACKNOWLEDGMENTS}

This study was partially funded by the Agencia Nacional de Investigación e Innovación - Uruguay (ANII) in the first year and by the Coordenação de Aperfeiçoamento de Pessoal de Nível Superior - Brazil (CAPES) in the second and third yeasr. The authors thank Embrapa Clima Temperado and all its staff, especially Everton Pederzolli and Gilberto Kuhn for their assistance in the experiments.

\section{CONFLICTS OF INTEREST}

The authors declare no conflict of interest.

\section{REFERENCES}

Agromet-Embrapa (2020). Agrometeorology laboratory, Embrapa Clima Temperado, Chill hours, Embrapa Sede Pelotas (Monte Bonito). Pelotas: Embrapa, 2019. Available at [http://agromet.cpact.embrapa.br/]. Accessed 23 nov. 2020.

Allard RW (1960). Principles of plant breeding. John Wiley and Sons, Inc., New York.

Baró-Montel N, Eduardo I, Usall J, Casals C, et al. (2019). Exploring sources of resistance to brown rot in an interspecific almond $\times$ peach population. J. Sci. Food Agr. 99: 4105-4113.

Byrne DH, Raseira MCB, Bassi D, Piagnani MC, et al. (2012). Peach. In: Fruit Breeding (Badenes ML, Byrne DH, eds.). Springer, New York.

Carpenedo S, Raseira MCB, Byrne DH and Franzon RC (2017). The effect of heat stress on the reproductive structures of peach. J. Am. Pomol. Soc. 71: 114-120.

Carpenedo S, Raseira MCB, Franzon RC, Byrne DH, et al. (2020). Stigmatic receptivity of peach flowers submitted to heat stress. Acta Sci. Agron. 42: e42450.

Centellas-Quezada A (2000). Herança da época de floração e da resistência à ferrugem da folha em pessegueiro. Doctor's thesis. Federal University of Pelotas, Pelotas.

Chen S, Yuan N, Schnabel G and Luo C (2017). Function of the genetic element 'Mona' associated with fungicide resistance in Monilinia fructicola. Mol. Plant Pathol. 18: 90-97.

Citadin I, Scariotto S, Sachet MR, Rosa FJ, et al. (2014). Adaptability and stability of fruit set and production of peach trees in a subtropical climate. Sci. Agr. 71: 133-138.

Corrêa ER (2007). Estudo da herdabilidade de alguns carácteres em pessegueiro: ciclo, tonalidade da cor da polpa e compostos fenólicos. Master's thesis. Federal University of Pelotas, Pelotas. Available at [http://guaiaca.ufpel.edu.br/handle/123456789/2113]. Accessed 13 jun. 2020.

Dirlewanger E, Quero-García J, Le Dantec L, Lambert P, et al. (2012). Comparison of the genetic determinism of two key phenological traits, flowering and maturity dates, in three Prunus species: peach, apricot and sweet cherry. Heredity. 109: 280-292.

Eler JP (2014). Teorias e métodos em melhoramento genético animal; I- Bases do melhoramento genético animal. 1st edn. University of São Paulo, Pirassununga.

Elshafie HS, Mancini E, Camele I, De Martino L, et al. (2015). In vivo antifungal activity of two essential oils from Mediterranean plants against postharvest brown rot disease of peach fruit. Ind. Crop. Prod. 66: 11-15.

Fadón E, Herrera S, Guerrero BI, Guerra ME, et al. (2020). Chilling and heat requirements of temperate stone fruit trees (Prunus sp.). Agronomy. 10: 409.

Falconer DS and Mackay TFC (2001). Introducción a la genética cuantitativa. Acribia S.A, Zaragosa.

Frett TJ (2016). Genetic determinism of Xanthomonas arboricola pv. pruni (Xap) resistance, fruit quality, and phenological traits in peach and incorporation of marker-assisted aelection (MAS) in the University of Arkansas peach and nectarine breeding program. Doctor's thesis. Clemson University, Arkansas. Available at [https://scholarworks.uark.edu/etd/1448/]. Accessed 28 jun. 2020.

Fu W, Tian G, Pei Q, Ge X, et al. (2017). Evaluation of berberine as a natural compound to inhibit peach brown rot pathogen Monilinia fructicola. Crop Prot. 91: 20-26.

Griffiths AJF, Wessler SR, Carroll SB and Doebley J (2015). Introduction to Genetical Analysis. 10th edn. W. H. Freeman and Company, New York.

Hansche PE (1986). Heritability of fruit quality traits in peach and nectarine breeding stocks dwarfed by the $d w$ gene. HortScience. 21: 1193-1195.

Hansche PE (1990). Heritability of spring bloom and fall leaf abscission dates in Prunus persica. HortScience. 25: 16391641.

Genetics and Molecular Research 20 (1): gmr18684 
Hansche PE, Hesse CO and Beres V (1972). Estimates of genetic and environmental effects on several traits in peach. $J$. Am. Soc. Hortic. Sci. 97: 76-79.

Hartmann TP (2013). Heritability and phenotypic correlations in peach [Prunus persica (L.) Batsch]. Master's thesis. Texas AandM University, Texas. Available at [https://oaktrust.library.tamu.edu/handle/1969.1/151875]. Accessed 18 jun. 2020.

Hily JM, Singer SD, Villani SM and Cox KD (2011). Characterization of the cytochrome b (cyt b) gene from Monilinia species causing brown rot of stone and pome fruit and its significance in the development of QoI resistance. Pest Manag. Sci. 67: 385-396.

Londero PMG, Ribeiro ND, Cerutti T, Mazeiro SM, et al. (2009). Maternal effect in sulfur amino acids content expression in common bean grains. Cienc. Rural. 39: 1884-1887.

Luo CX, Hu MJ, Jin X, Yin LF, et al. (2010). An intron in the cytochrome $b$ gene of Monilinia fructicola mitigates the risk of resistance development to Qol fungicides. Pest Manag. Sci. 66: 1308-1315.

May-De Mio LL, Moreira LM, Monteiro LB and Justiniano Júnior PR (2008). Infection of Monilinia fructicola in budding stages and incidence of brown rot on fruits in two peach production systems. Trop. Plant Pathol. 33: 227234.

Mondino P, Alaniz S and Leoni C (2010). Manejo integrado de las enfermedades del duraznero en Uruguay. In: Manual del duraznero; Manejo integrado de plagas y enfermedades (Soria J, ed.). INIA, Montevideo.

Pommer CV and Barbosa W (2009). The impact of breeding on fruit production in warm climates of Brazil. Rev. Bras. Frutic. 31: 612-634.

Ramalho MAP, Santos JB, Pinto CBP, Souza EA, et al. (2012). Genética na agropecuária. UFLA, Lavras.

Raseira MCB, Pereira JFM and Carvalho FLC (2014). Pessegueiro. 1st edn. Embrapa, Brasília.

Razavi F, Hajilou J, Tabatabaei SJ and Dadpour MR (2011). Comparison of chilling and heat requirement in some peach and apricot cultivars. Res. Plant Biol. 1: 40-47.

R Core Team (2020). R: A language and environment for statistical computing. R Foundation for Statistical Computing, Vienna, Austria.

Roach DA and Wulff RD (1987). Maternal effects in plants. Annu. Rev. Ecol. Syst. 18: 209-235.

Souza VAB, Byrne DHE and Taylor JF (1998). Heritability, genetic and phenotypic correlations, and predicted selection response of quantitative traits in peach: II. An analysis of several fruits traits. J. Am. Soc. Hortic. Sci. 123: 604-611.

Vileila-Morales EA, Sherman WB, Wilcox CL and Andrews CP (1981). Inheritance of short fruit development period in peach. J. Am. Soc. Hortic. Sci. 106: 399-401.

Wagner Júnior A, Raseira MCB, Pierobom CR and Silva JB (2008). Evaluation of peach fruit reaction to inoculation with Monilinia fructicola (Wint.) Honey. Ceres. 55: 83-88.

Wu BH, Zhao JB, Chen J, Xi HF, et al. (2012). Maternal inheritance of sugars and acids in peach (P. persica (L.) Batsch) fruit. Euphytica. 188: 333-345.

Zhu F, Bryson PK and Schnabel G (2012). Influence of storage approaches on instability of propiconazole resistance in Monilinia fructicola. Pest Manag. Sci. 68: 1003-1009. 